\title{
Study on Approaches to Improve the Ability to Innovate of Students in Higher Vocational Colleges in Scientific Research Practice
}

\author{
Jing LV \\ Xi'an Aeronautical Polytechnic Institute, Xi'an 710089, China. \\ xihang710089@163.com
}

\begin{abstract}
Keywords: students in higher vocational colleges, scientific research practice, ability to innovate, discipline and skill contests, national students' platform for innovation and entrepreneurship training program, innovative talents.
\end{abstract}

\begin{abstract}
. it had become an important objective of higher vocational education to cultivate highskilled and innovative talents and improve the ability to innovate of students in higher vocational colleges. Engaging students in higher vocational colleges in scientific research practice activities was an important approach to improve their ability to innovate. This paper analyzed the original driving force provided by scientific research practice for the improvement of the ability to innovate of students in higher vocational colleges from the aspects of cultivation of great country craftsmen, connotation development of higher vocational colleges and self-accomplishment of students and stated the approaches and methods provided by scientific research practice to cultivate the ability to innovate of students in higher vocational colleges from the aspects of engagement in teachers' or optional scientific research projects, participation in various scientific and technological innovation clubs outside class, utilization of discipline and skill contests and the national students' platform for innovation and entrepreneurship training program, use of experimental and practical training bases inside and outside school and combination of graduation projects and training of scientific research innovation.
\end{abstract}

\section{Introduction}

For higher vocational colleges which serve as the major force to cultivate and produce front-line high-skilled and innovative talents, how to strengthen the cultivation of the spirit of innovation and ability to innovate of students in higher vocational colleges under the new circumstances of developing an innovative society and how to complete the transformation of vocational education in China from quantity-oriented to quality-oriented have become the keys for higher vocational education to achieve the objectives of talent cultivation. It is not only an approach for improving the quality of the talents cultivated through higher vocational education but also an important means for strengthening the connotation construction of higher vocational education for higher vocational colleges to encourage students to participate in scientific research practice activities and cultivate their ability to innovate. "Providing scientific research training for college students is widely considered an important index to measure the quality of undergraduate education and an effective approach to improve college students' ability to innovate."[1] This study as well as its conclusion is equally applicable to higher vocational education except that it is necessary to highlight the objective of higher vocational education to cultivate high-skilled and innovative talents in terms of specific approaches and methods.

With considerable attention attached to the work of cultivating innovative talents in higher vocational colleges, the Ministry of Education has successively issued a series of documents with respect to the Action Plan for the Innovative Development of Higher Vocational Education [2-3] in order to vigorously advance the reform and development of innovation education in higher vocational colleges. In the critical period of the reform and development of the "Thirteenth Five-Year Plan", higher vocational colleges must deeply understand that innovation and entrepreneurship education is a national strategy and what important responsibilities they have in the cultivation of high-skilled and innovative talents in the period of the "Thirteenth Five-Year Plan". 


\section{Analysis on the Driving Force Provided by Scientific Research Practice to Improve the Ability to Innovate of Students in Higher Vocational Colleges}

\subsection{Scientific Research Promoting Innovation as a Requirement of Our Country to Forge Great Country Craftsmen}

As the era of knowledge-driven economy develops, whether or not being equipped with consciousness of innovation and ability to innovate has not only become one of the key factors of employment competitiveness of students in higher vocational colleges, but also decided if they have any potential or space for further development. Students in higher vocational colleges are our country's high-skilled and innovative talents -- one of the main resource reserve pools of great country craftsmen. The level of innovation of students in higher vocational colleges has significant influence on the level of innovative development and development of the economic society of our country. The improvement of the cultivation of the ability to innovate of students in higher vocational colleges involves not only the cultivation of their ability to innovate at the professional and technical level but also the improvement of their comprehensive quality and the perfection of their personality through scientific research practice in order to lay a good foundation for their future scientific research practice, innovation in a certain field, development and breakthrough. Therefore, in the transformation period of national economic development and under the circumstances of forming an innovative society, it is an inevitable choice for higher vocational colleges to encourage students to improve their consciousness of innovation and ability to innovate by participating in scientific research practice in order to cultivate and force great country craftsmen. It is an important mission for higher vocational education to improve students' ability to innovate and cultivate high-quality and innovative technical and skilled talents for docking with the national strategy of "Made in China 2025", adapting to the requirements of our country's economic development and transformation and laying a solid foundation for the construction of a manufacturing powerhouse.

\subsection{Scientific Research Promoting Innovation as a Requirement of the Connotation Development of Higher Vocational Colleges}

It is also a requirement of the structural adjustment and connotation development of higher vocational colleges to encourage students in higher vocational colleges to improve their ability to innovate by participating in scientific research practice. With the gradual deepening of the reform of higher vocational education, the development of higher vocational colleges is posed with an unprecedented severe challenge, i.e., the challenge on their core competitiveness, which is manifested as the quality of cultivated talents. Therefore, higher vocational colleges shall come up with more innovative talent cultivation modes, cultivate high-quality talents with innovative thinking and ability to innovate and improve the comprehensive quality of the talents during the participation of students in higher vocational colleges in scientific research practice. The cultivation and improvement of students' ability to innovate are the internal requirements and keys of the self-development of higher vocational colleges.

In order to become a true "base for knowledge innovation and cultivation of high-level innovative talents", higher vocational colleges shall increase the input of scientific research while improving teaching to give full expression to the property of scientific research of higher colleges. A study indicated that "scientific research training has influenced and changed students' ability to innovate, which indicates that scientific research training activities have a certain effect on the ability to innovate of college students"[4]. Therefore, higher vocational colleges may create various scientific research practice or project organizations covering as many various specialized fields and discipline categories of each college as possible combining with the characteristics of their respective disciplines and specialties.

\subsection{Scientific Research Promoting Innovation as a Requirement of the Self-Accomplishment of Students in Higher Vocational Colleges}

It is an internal requirement to encourage students in higher vocational colleges to participate in scientific research practice for their self-accomplishment. In order to become high-level professionals with high comprehensive quality and certain ability to innovate, students in higher vocational colleges are required to not only master specialized knowledge, but also be equipped with good moral 
character, harmonious interpersonal relationships and other non-professional elements. During the participation in scientific research practice, students in higher vocational colleges are required to collect and sort out a large amount of information resources through various approaches, work with multiple persons and their tutors in scientific research practice and even be involved in coordination among departments, which is a great help to the students' transformation from individualization to socialization as well as their healthy growth and improvement of their comprehensive quality. "The approach to cultivate college students' ability to innovate on the basis of being driven by scientific research projects belongs to the project-driven cultivation mode, the significance of which relies on the enhancement of college students' ability to apply their specialized knowledge in a comprehensive way and the creation of an environment favorable to the cultivation of ability to innovate." [5] In addition, students in higher vocational colleges may learn to think independently, develop a conscientious and pragmatic attitude and be practical and realistic during their participation in scientific research practice. It is an important approach for students in higher vocational colleges to consciously choose some major-related or interested knowledge and content to study and explore while learning specialized knowledge for the improvement of their ability of self-innovation and selfperfection. Therefore, encouraging and guiding students in higher vocational colleges to participate in scientific research is an effective approach to improve their ability to innovate and comprehensive quality.

\section{Approaches and Methods for Students in Higher Vocational Colleges to Improve Their Ability to Innovate by Participating in Scientific Research Practice}

It is not only an important direction for the transformation of talent cultivation methods but also the objective of talent cultivation of higher vocational education to improve the ability to innovate of students in higher vocational colleges by encouraging them to participate in scientific research practice. Therefore, higher vocational colleges, especially those specialized in engineering, shall pay more attention to the approach of cultivating students' ability to innovate by engaging them in scientific research practice, take the initiative to establish platforms for scientific research and encourage students in higher vocational colleges to actively participate in scientific research practice activities. Platforms for scientific research include sites, apparatus and equipment, literature and personnel, funds, policies and institutions and other tangible and intangible resources. The construction and implementation of such platforms have significant influence on the successful progress of scientific research practice. Higher vocational colleges shall encourage students to participate in scientific research practice. In order to improve the students' ability to innovate through scientific research practice, it is necessary to further construct and improve the platforms and environment for scientific research inside and outside school to provide better services for the improvement of students' ability to innovate through scientific research practice. The main approaches and methods include:

\subsection{Engagement in Teachers' or Optional Scientific Research Projects}

The form of students "assisting in research" shall be adopted to encourage students to participate in scientific research practice. Starting from school-level projects, the scope of participation shall be gradually extended to vertical and horizontal scientific research. Students in higher vocational colleges with a certain foundation for research related to their respective majors shall be guided to participate in teachers' or enterprises' scientific research projects and be involved in actual scientific research practice in order to deepen and transform the students' specialized knowledge during scientific research practice. For example, the teacher can ask the students to write down the topics they want to study for this semester according to the lessons, and then classify the students based on the similarity of interest and divide them into research teams each with 4 to 6 members. The students will begin to study their issues as scientific research teams from the second week and the teacher will become their mentor instead of simply giving lectures in class. The students will design a scheme for studying their issues and prepare for their defense in the last two weeks. The final results will be composed of a team score and each member's bonus points for their contribution to the topic. It is also feasible to set up specialized scientific research projects according to different specialty 
categories in order to provide as many opportunities for scientific research practice as possible for students in higher vocational colleges and improve their selectivity and interactivity for scientific research practice.

Each department can appoint backbone teachers or academic leaders with scientific research capability as tutors for students to cultivate their ability to do research and innovate. Teachers can provide students with instructions on information retrieval and data analysis regularly. After carrying out certain scientific research practice, a batch of students with keen interest in scientific research and stronger scientific research capacity can be selected based on the results of the teachers' instruction for intensive training.

Meanwhile, tutors shall be awarded with certain honor as an affirmation and compensated for their workload and the teachers and schools with better results shall be recognized and awarded bonus points in the annual scientific research evaluation. In addition, each professional school (department) shall provide convenience for students to participate in scientific research practice. Furthermore, higher vocational colleges with adequate conditions can equip every class with a scientific research secretary with relatively strong scientific research capability to be responsible for the instruction and the overall arrangement for students-involved scientific research practice and guarantee the standards and order of students-involved scientific research.

\subsection{Participation in Various Scientific and Technological Innovation Club Activities outside Class}

Students just enrolled in higher vocational colleges shall be guided promptly to participate in extracurricular technological activities combining their respective specialties in order to help them familiarize themselves with their respective specialties as soon as possible. Colleges can encourage students to actively participate in various technological innovation club activities through all kinds of lectures and the guidance of objectives of various kinds of contests and arouse students' keen interest in technological activities and scientific research practice as the willingness to try and explore is a precondition to guarantee the participation of students in higher vocational colleges in scientific research practice.

It is also feasible to organize students to participate in extracurricular technological activities, such as technological and academic festivals, and arouse the enthusiasm of students to participate in scientific research practice and innovation. Outside class, all kinds of colorful activities, such as innovation knowledge lectures, innovation salons and technological contests, shall be carried out to expand the vision and increase the knowledge reserve of students and enable them to learn more innovation knowledge and innovation skills.

For example, Xi'an Aeronautical Polytechnic Institute has been encouraging its teachers and students to form technology clubs and scientific research teams. Through the joint exploration and experiment of teachers and students, the students have developed a comprehensive understanding of scientific research practice and taken the initiative to put forward innovative conceptions during the practice, based on which, the development of technological and innovative student clubs and organizations has been advanced and 17 technological and innovative clubs, such as Lanxiang Model Airplane Club, Mathematical Modeling Innovation Association, Robot Factory and so on, have been successively established, effectively promoting the carrying out of extensive technological and innovative practice.

\subsection{Utilization of Discipline and Skill Contests and the National Students' Platform for Innovation and Entrepreneurship Training Program}

At present, the national discipline and skill contests participated by students in higher vocational colleges in China mainly include: National Undergraduate Electronics Design Contest, China Undergraduate Mathematical Contest in Modeling, National College Mechanical Design and Structural Design Contest, China Aeromodelling Design Challenge, Robot Contest and so on. In addition, there are more than 40 discipline and skill contests of all kinds at the school level, municipal level and provincial level. Students in higher vocational colleges are also involved in national and provincial college student innovation and entrepreneurship training programs. Higher vocational colleges shall take full advantage of above discipline contests of various kinds at various levels and 
the students' platform for innovation and entrepreneurship training program to guide and instruct students to participate in technological and innovative activities. Higher vocational colleges shall open and share their existing scientific research platforms to and with the students who participate in technological and innovative activities and equip them with tutors to strengthen training and instructions. Students in higher vocational colleges have not only developed their team work spirit and ability, but also taken the initiative to discover and solve problems by participating in various discipline and skill contests and activities under college student innovation and entrepreneurship training programs, laying an important foundation for the cultivation of technological innovation ability.

\subsection{Use of Experimental and Practical Training Bases Inside and Outside School for the Carrying-Out of Technological Innovation}

All schools (departments) of higher vocational colleges shall fully rely on their professional advantages to hold various kinds of innovation contests with themes such as technological innovation, creative design and innovative plan jointly with industrial enterprises, which provides not only an important platform for students to show their technological innovation results but also solutions to the enterprises' actual problems. In order to provide a necessary material basis for students in higher vocational colleges to participate in scientific research and improve their ability to innovate, it is required to rely on industrial and regional advantages, actively utilize the practical training bases outside school, cooperate with industrial companies or enterprises, participate in study on horizontal enterprise projects and take advantage of their advanced production and laboratory equipment, plants and workshops to carry out experiments and practical training and technological innovation activities. By taking advantage of its location at a national air base and closely relying on the industry, Xi'an Aeronautical Polytechnic Institute has integrated the large platforms of resources in the aviation industry at home and overseas, strengthened the Industry-Academy-Research cooperation around the key technology of aircraft manufacturing, kept innovating in the industry sector, including technological innovation, talent innovation, industrial innovation and such, strengthened its close integration with industrial enterprises and sped up the cultivation of innovative talents.

\subsection{Combination of Graduation Projects and Training of Scientific Research Innovation}

Graduation projects shall be combined with teachers' scientific research or student discipline contests according to the principle of Industry-Academy-Research integration. At present, there are a lot of discipline and skill contests designed for students in higher vocational colleges. Except for the national and provincial discipline and skill contests and college student innovation and entrepreneurship training programs, there are also Computer Simulation Contest, Mechanical Innovation Design Competition and other competitions for students in higher vocational colleges. Teachers can guide students in an appropriate way to organically integrate their entries and training programs with graduation design in order to better arouse the initiative, enthusiasm and creativity to work on their graduation design, which has not only facilitated the improvement of the quality of their graduation design works, but also achieved the effective integration between scientific research and teaching of specialized courses as well as the organic combination of industry, academy and research.

Under the guidance of scientific research and innovation training projects, encouraging students to choose the direction for their graduation design based on their own interest and be engaged in work of choosing a topic independently, designing experiments and practical training independently, establishing and implementing experiments and practical training, analyzing data, writing reports and such under the instruction of their teachers can not only arouse the enthusiasm of students, but also guarantee the efficiency and quality of teachers' instruction on students. Tutors can personally carry out experiments and practical training with students and instruct them from the aspects of thinking methods, experimental skills, ability to innovate, etc. It is also feasible to encourage students to publish their graduation theses on domestic and foreign academic periodicals for the public or transform their research results to production. Integrating scientific research training with graduation design of students in higher vocational colleges can not only significantly improve their ability to 
practice and innovate, but also cultivate creativity and innovative thinking, playing a positive role in the intensive education on the innovation quality for scientific research.

\section{Conclusion}

From the perspectives of employment, further study and effective serving the society of students in higher vocational colleges, it is an inevitable requirement for students in higher vocational colleges to participate in scientific research practice for the cultivation of innovative and high-quality talents under the new circumstances. As the employment situation for college graduates becomes more and more serious under the new circumstances, employers are demanding more and more on students in higher vocational colleges. Talents with consciousness of innovation, ability to innovate and team spirit are more welcomed by employers. Students who take advantage of various opportunities for scientific research practice and intent to improve their consciousness of innovation and ability to innovate with clear targets and emphases at higher vocational colleges are undoubtedly more competitive in terms of employment.

The cultivation of students' consciousness of innovation and ability to innovate is not only an important issue faced by higher vocational colleges but also the bottleneck of the talent cultivation in higher vocational colleges at present. "The cultivation of consciousness of innovation and ability to innovate must be a step-by-step process instead of being accomplished in an action."[6] China's economy is undergoing the critical period of innovation-driven transformation and development. As a major force with the most direct and significant relation to economic development for the cultivation of high-skilled and innovative talents, higher vocational colleges must practically incorporate the participation of students in scientific research practice and the improvement of the cultivation of students' ability to innovate into educational philosophy, utilize their own resources to serve national strategies and cultivate high-skilled and innovative talents in order to improve the actual effect of the cultivation objectives of higher vocational education.

\section{Acknowledgments}

The 2017 scientific research project of the education department of shaanxi province,Project name: research and practice of scientific research management mode based on service concept -- taking xi 'an aviation vocational and technical college as an example. project number:17JK0399.

\section{References}

[1]. Zhang Aihua. Implementation of and inspiration from undergraduate scientific research training programs in domestic and foreign research universities [J]. Science \& Technology Information, 2007 (24): 109-109.

[2]. Several Opinions of the Ministry of Education on Advance of the Reform and Innovation of Higher Vocational Education Leading the Scientific Development of Vocational Education, website of the Ministry of Education [EB/OL]. http: // www. Moe. gov. cn / srcsite/ A07/ s7055 /201109/t20110929_171561.html.

[3]. Action Plan for the Innovative Development of Higher Vocational Education (2015 - 2018), website of the Ministry of Education [EB/OL]. http: //www. moe.edu. cn/srcsite/A07/moe_737/ s3877/201511/t20151102_216985.html.

[4]. Jiang Yin. Research on different impacts of scientific research training activities on college students' ability to innovate [J]. Academic Journal of Changchun University Of Technology (Higher Education Research Edition), 2010, 31(2): 31-33.

[5]. Bai Wenyuan, Zhang Wenzheng. Exploration on management modes of college student scientific research training programs [J]. Research in Teaching, 2010 (4): 99-102. 
[6]. Bie Jun, Wei Xiaowei. Encouraging college students to actively participate in scientific research and cultivate high-quality innovative talents [J]. Research on Higher Education, 2011, 28 (2): 8591. 